\title{
Influence of Variety and Nitrogen Fertilization on the Technological Parameters of Special Malts Prepared from Naked and Hulled Oat Varieties
}

\author{
Józef Błażewicz ${ }^{1}$, Joanna Kawa-Rygielska ${ }^{1}$, Danuta Leszczyńska ${ }^{2, *} \mathbb{C}$, Jerzy Grabiński ${ }^{2}\left(\mathbb{C}\right.$ and Alan Gasiński ${ }^{1, *}$ \\ 1 Department of Fermentation and Cereals Technology, Faculty of Biotechnology and Food Science, \\ Wrocław University of Environmental and Life Science, Chełmońskiego 37 Street, 51-630 Wroclaw, Poland; \\ jozef.blazewicz@upwr.edu.pl (J.B.); joanna.kawa-rygielska@upwr.edu.pl (J.K.-R.) \\ 2 Department of Cereal Crop Production, Institute of Soil Science and Plant Cultivation-State Research \\ Institute, Czartoryskich 8, 24-100 Puławy, Poland; jurek@iung.pulawy.pl \\ * Correspondence: leszcz@iung.pulawy.pl (D.L.); alan.gasinski@upwr.edu.pl (A.G.)
}

check for updates

Citation: Błażewicz, J.;

Kawa-Rygielska, J.; Leszczyńska, D.; Grabiński, J.; Gasiński, A. Influence of Variety and Nitrogen Fertilization on the Technological Parameters of Special Malts Prepared from Naked and Hulled Oat Varieties. Agronomy 2021, 11, 2566. https://doi.org/ 10.3390 /agronomy 11122566

Academic Editor: Helen Suter

Received: 27 October 2021

Accepted: 16 December 2021

Published: 17 December 2021

Publisher's Note: MDPI stays neutral with regard to jurisdictional claims in published maps and institutional affiliations.

Copyright: (c) 2021 by the authors. Licensee MDPI, Basel, Switzerland. This article is an open access article distributed under the terms and conditions of the Creative Commons Attribution (CC BY) license (https:// creativecommons.org/licenses/by/ $4.0 /)$.

\begin{abstract}
Grains of four naked oat varieties (Amant, Maczo, Polar and Siwek) and one hulled oat variety (Kozak) from three consecutive years (2018, 2019 and 2020), grown under three different nitrogen fertilization regimes (40,60 and $80 \mathrm{~kg}$ of nitrogen per hectare) were malted and then mashed in the laboratory conditions for the first time; this was carried out to determine whether hulled and naked oat grains possess favourable properties as a raw material for the production of malt. Most of the analysed samples possess a favourable Kolbach index (39.06-46.82\%), good extractivity (81.07-81.97\%) and rather good saccharification time (13.33-26.67 $\mathrm{min})$; however, some disadvantages of the produced malts could be pointed out. During the congress mashing, the filtration time of the worts produced from the hulled and naked oat malts was long (96.67-110 $\mathrm{min}$ ) and the wort volume was not satisfactory (155-228.53 mL). Subsequent studies over oat malting and mashing need to be performed to maximize oat potential as the raw material for the production of the malt.
\end{abstract}

Keywords: hulled oat; naked oat; congress wort; malt; mashing; nitrogen fertilization

\section{Introduction}

Malting is a technological process mainly used to modify grains of barley (Hordeum vulgare L.) [1]. During the malting process, grains are steeped, germinated and then kilned (dried with hot air). The goal of the malting is the production of various enzymes, mainly amylases and proteases, the change of the grain structure (to make it more friable) and the addition of appropriate sensory features [2]. This process can be used to obtain malts from cereal grains, as well as pseudocereals and various seeds of other arable crops [3-5]. Malt is typically used for the production of beer and other cereal-based alcoholic beverages. Oat flakes and oat malt, produced from the hulled oat (Avena sativa), are often used in many of the so-called "new-wave" beer styles [6]. However, addition of the oat malt or various oat products from the hulled oat varieties for the production of wort can hinder wort filtration. In the available scientific literature, only a few publications about the possibilities of producing beer with $100 \%$ oats (from the hulled variety) in the grain bill can be found. Technology of oat wort production requires modification of the traditional mashing process [6,7]. In the literature, there is not much information about the possibility of using naked oat grains for the production of worts and beer [8]. Naked oat most likely originated in Mongolia and northern China [9]. It is a plant that can be successfully grown on a wide variety of soils and geographical latitudes [10-12]. Oats possess various advantages over barley, which is why it would be beneficial to determine whether this material could be used for the brewing industry. Some researchers have found that oat yields much more dry matter compared with barley, while being grown in semiarid regions, which might be more and more present around the globe due to climate change [13-15]. 
Current changes in the climate show that barley, with proper malting properties, might be far harder to cultivate in the future, which is why it is important to find various cereal alternatives [16-18]. Furthermore, currently, in Poland and the world, there are tremendous amounts of cereal monocultures being grown, which have an impact on the depletion of soil $[19,20]$. Increasing the amount of naked oat cultures being grown might also be advantageous for the biodiversity of the regions, as the naked oat is not currently grown on a large scale [21,22]. Additionally, oat possesses advantages over many cereals being grown in the region-including a resistance to Fusarium infections-and consecutive years of naked oat cultivation might prove beneficial for the farmers [23-25]. The aim of this work was the technological assessment of malting properties of the four commercial varieties of naked oat (Amant, Maczo, Polar and Siwek) and one commercial variety of hulled oat (Kozak), registered in the Research Centre for Cultivars Testing of the Republic of Poland. The analysed material came from the consecutive growing seasons from a strict fertilization experiment in which oat (hulled and naked) were fertilized with various nitrogen dosages, ranging from 40 to $80 \mathrm{~kg}$ of nitrogen per hectare. Proper fertilization with nitrogen might be crucial in the cultivation of oat for brewing purposes, because it is one of the most important factors affecting grain yield and protein content of the grain. Adequate protein content of grains is indispensable for production of good quality malt, because malt needs to have adequately high enzyme activity. However, grains with very high protein content typically have lower starch concentration, which diminishes their value as a malting material [2]. Due to these factors, analysis of the proper nitrogen fertilization rate would be of value for farmers, who would like to cultivate oat for the purposes of supplying the malting and brewing industry.

\section{Materials and Methods}

\subsection{Plant Material}

The plant material used in this study were grains of naked oat of the four commercial varieties: Amant, Maczo, Polar and Siwek; grains of hulled oat of one variety: Kozak. Grains of varieties Amant, Maczo, Polar and Kozak varieties were acquired from Hodowla Roślin Strzelce (Plant Breeding Strzelce), IHAR Group (Strzelce, Poland) and grains of Siwek variety were acquired from Małopolska Hodowla Roślin (Lesser Poland Voivodeship Plant Breeding Station) (Kraków, Poland). Grains were planted and harvested in the years 2018, 2019 and 2020 at the Experimental Station of The Institute of Soil Science and Plant Cultivation, State Research Institute in Osiny $\left(51^{\circ} 27^{\prime} \mathrm{N} ; 22^{\circ} 22^{\prime} \mathrm{E}\right)$. The plants were rainfed during the vegetation period. The amount of rainfall each year did not deviate from multi-year (30-year period) of rainfall in this region. The total amount of rainfall during the vegetation period (May-August) in 2018 was $308.7 \mathrm{~mm}$, in 2019 it was $303.6 \mathrm{~mm}$ and in 2020 it was $359.3 \mathrm{~mm}$, while the average was $329 \mathrm{~mm}$. The research plots (length of $15 \mathrm{~m}$, width of $3 \mathrm{~m}$ ) were located on the lessive soil (Luvisol) [26]. Oats were grown with the use of various dosages of nitrogen fertilizer, equal to 40,60 or $80 \mathrm{~kg}$ of nitrogen per hectare, using ammonium nitrate (34\%). The experiment was established using random subblocks in the split-block method in 4 replications, on plots sized $45 \mathrm{~m}^{2}$ (length $15 \mathrm{~m}$, width $3 \mathrm{~m}$ ). The variety factor was randomized in the main block and concentration of the fertilizer used was randomized in the subblock. Sowing treatments were performed in accordance with good agriculture practice and sowing was performed at the optimum time (the same day for each of the varieties). The sowing rates were 500 grains per $1 \mathrm{~m}^{2}$. The row spacing was $12 \mathrm{~cm}$ and the sowing depth was $3 \mathrm{~cm}$. Oat grains of all the varieties were planted the same day each year. During the oat vegetative period, the protection of oat was applied with the recommendation of the Institute of Plant Protection-State Research Institute in Poznan. The grains of the oat cultivars were harvested at the stage of full maturity of cereals (code 89 from the $\mathrm{BBCH}$ scale), which occurred at the same day for each of the varieties and years [27]. Cereals were used to produce malts in the laboratory conditions described in Section 2.2. and malts were used to produce congress worts, according to the Analytica EBC [28]. Abbreviations of the samples are shown in Table 1. 
Table 1. Abbreviations of the tested samples.

\begin{tabular}{|c|c|c|c|}
\hline Abbreviation & Variety & $\begin{array}{c}\text { Nitrogen } \\
\text { Fertilization } \\
{[\mathrm{kg} \mathrm{N} / \mathrm{ha}]}\end{array}$ & Type \\
\hline K40G & Kozak (hulled oat) & 40 & Grain \\
\hline K60G & Kozak (hulled oat) & 60 & Grain \\
\hline K80G & Kozak (hulled oat) & 80 & Grain \\
\hline A40G & Amant (naked oat) & 40 & Grain \\
\hline A60G & Amant (naked oat) & 60 & Grain \\
\hline A80G & Amant (naked oat) & 80 & Grain \\
\hline M40G & Maczo (naked oat) & 40 & Grain \\
\hline M60G & Maczo (naked oat) & 60 & Grain \\
\hline M80G & Maczo (naked oat) & 80 & Grain \\
\hline P40G & Polar (naked oat) & 40 & Grain \\
\hline P60G & Polar (naked oat) & 60 & Grain \\
\hline P80G & Polar (naked oat) & 80 & Grain \\
\hline S40G & Siwek (naked oat) & 40 & Grain \\
\hline S60G & Siwek (naked oat) & 60 & Grain \\
\hline S80G & Siwek (naked oat) & 80 & Grain \\
\hline K40M & Kozak (hulled oat) & 40 & Malt \\
\hline K60M & Kozak (hulled oat) & 60 & Malt \\
\hline K80M & Kozak (hulled oat) & 80 & Malt \\
\hline $\mathrm{A} 40 \mathrm{M}$ & Amant (naked oat) & 40 & Malt \\
\hline $\mathrm{A} 60 \mathrm{M}$ & Amant (naked oat) & 60 & Malt \\
\hline $\mathrm{A} 80 \mathrm{M}$ & Amant (naked oat) & 80 & Malt \\
\hline $\mathrm{M} 40 \mathrm{M}$ & Maczo (naked oat) & 40 & Malt \\
\hline M60M & Maczo (naked oat) & 60 & Malt \\
\hline M80M & Maczo (naked oat) & 80 & Malt \\
\hline P40M & Polar (naked oat) & 40 & Malt \\
\hline P60M & Polar (naked oat) & 60 & Malt \\
\hline P80M & Polar (naked oat) & 80 & Malt \\
\hline S40M & Siwek (naked oat) & 40 & Malt \\
\hline S60M & Siwek (naked oat) & 60 & Malt \\
\hline S80M & Siwek (naked oat) & 80 & Malt \\
\hline K40W & Kozak (hulled oat) & 40 & Wort \\
\hline K60W & Kozak (hulled oat) & 60 & Wort \\
\hline K80W & Kozak (hulled oat) & 80 & Wort \\
\hline A40W & Amant (naked oat) & 40 & Wort \\
\hline A60W & Amant (naked oat) & 60 & Wort \\
\hline A80W & Amant (naked oat) & 80 & Wort \\
\hline M40W & Maczo (naked oat) & 40 & Wort \\
\hline M60W & Maczo (naked oat) & 60 & Wort \\
\hline M80W & Maczo (naked oat) & 80 & Wort \\
\hline P40W & Polar (naked oat) & 40 & Wort \\
\hline P60W & Polar (naked oat) & 60 & Wort \\
\hline P80W & Polar (naked oat) & 80 & Wort \\
\hline S40W & Siwek (naked oat) & 40 & Wort \\
\hline S60W & Siwek (naked oat) & 60 & Wort \\
\hline S80W & Siwek (naked oat) & 80 & Wort \\
\hline
\end{tabular}

\subsection{Malting Procedure}

\subsubsection{Steeping and Germination of the Oat Grains}

Prior to the steeping process, the moisture of the grains was analysed using Infratec 1241 Grain Analyzer (Foss, Hilleroed, Denmark). Grains with any dimensions lower than $2.2 \mathrm{~mm}$ were discarded through sifting with the use of Laboratory Sorting Machine Sortimat (Pfeuffer GMBH, Kitzingen, Germany). Fifty grams portions of naked oat grains of varieties Amant, Maczo, Polar, Siwek and hulled oat rains of variety Kozak were weighed and measured into perforated stainless steel malting containers. Weight of the malting kits (which consisted of container and grain sample) were measured. Changes in the moisture 
content of the grain during the steeping process were assessed by the changing weight of the malting kit, with the assumption that the increase in weight is equal to the weight of the water absorbed by the grains.

Steeping was executed in the water-air steeping cycle by submerging malting kits in tap water for $5 \mathrm{~h}$ (at temperature of $15^{\circ} \mathrm{C}$ ); removing containers from the water and storing them in a humid air in a refrigerated germination chamber $\left(95 \%\right.$ relative humidity, $\left.15^{\circ} \mathrm{C}\right)$ for $19 \mathrm{~h}$; submerging containers in fresh tap water for $5 \mathrm{~h}\left(15^{\circ} \mathrm{C}\right)$; air rest of grain steeping by storing the containers in the germination chamber $\left(95 \%\right.$ relative humidity, $\left.15^{\circ} \mathrm{C}\right)$ for another $19 \mathrm{~h}$. After $48 \mathrm{~h}$ of steeping sequence, oat grains acquired a moisture level equal to $45 \%$.

Grain was kept in the refrigerated germination chamber $\left(\right.$ at $15{ }^{\circ} \mathrm{C}$ and $95 \%$ relative humidity) for $144 \mathrm{~h}$. Every $24 \mathrm{~h}$, grains were mixed manually to prevent roots entanglement and were sprayed with distilled, sterile water to eliminate water deficiencies and maintain constant humidity throughout germination.

\subsubsection{Kilning and Grinding of the Oat Malt}

Kilning of the germinated hulled oat and naked oat grains was performed immediately after $144 \mathrm{~h}$ of grain germination. Malting containers were loaded into a UF110 Plus dryer (Memmert $\mathrm{GmbH}+\mathrm{Co}$, Schwabach, Germany) and kilned in the following temperature and heating conditions: $50^{\circ} \mathrm{C}(17 \mathrm{~h}$ and $50 \mathrm{~min})$, ramp up to $65^{\circ} \mathrm{C}(10 \mathrm{~min}), 65^{\circ} \mathrm{C}(2 \mathrm{~h}$ and $50 \mathrm{~min})$, ramp up to $82^{\circ} \mathrm{C}(10 \mathrm{~min}), 82^{\circ} \mathrm{C}(2 \mathrm{~h})$. After kilning, malts of each type were mixed and transferred into tightly closed containers, which prevented moisture absorption during the cooling period. After temperature of malt dropped to $20^{\circ} \mathrm{C}$, rootlets of the malt were manually removed and malt was ground on the Bühler Miag disc mill DLFU (Bühler, Uzwil, Switzerland), according to the Analytica EBC (European Brewery Convention) method [28].

\subsection{Analyses of the Grains and Malts}

Grains and malts were assessed using the same apparatus, the Infratec 1241 Grain Analyzer, each year.

\subsubsection{Basic Physical Properties of the Grains}

Concentration of protein and starch, as well as moisture of the grains, was assessed with the use of the Infratec 1241 Grain Analyzer using near infrared spectroscopy. Impurities from the grain were removed by sieving through the Sortimat machine equipped with 2.8, 2.5 and $2.2 \mathrm{~mm}$ sieves. Sieved grain sample was loaded into the hopper of Infratec and analysis was performed automatically, using the parameters integrated in the apparatus, provided by the manufacturer. Each of the cereals was assessed in triplicate each year, using ten subsamples for each measurement.

\subsubsection{Technological Parameters of the Malt}

Malt extractivity (ratio, in which substances present in the malt are transferred to the wort), concentration of protein and concentration of soluble protein and moisture were analysed with the use of the Infratec 1241 Grain Analyzer using near infrared spectroscopy. Deculmed malt was loaded into the hopper of Infratec and analysis was performed automatically, using the parameters integrated in the apparatus, provided by the manufacturer. Each of the malts was assessed in triplicate each year, using three subsamples for each measurement.

\subsubsection{Soluble Nitrogen Ratio (Kolbach Index)}

Soluble nitrogen ratio of the malts was based on the concentration of soluble protein present in the malt and concentration of total protein in the malt and calculated according to the formula below [29]:

$$
\mathrm{SNR}=\mathrm{S} / \mathrm{T} \cdot 100 \%
$$


$\mathrm{S}$ - concentration of the soluble protein in the malt ( $\% w / w$, dry mass)

$\mathrm{T}$-concentration of total protein in the malt ( $\% w / w$, dry mass)

\subsubsection{Thousand Grain Weight of Grain and Malt}

Thousand grain weight (TGW) was assessed using LN-S-50 Grain Counter (Unitra, Szczytno, Poland). Grains sorted with the use of Sortimat as well as deculmed malt were loaded into the hopper of counter, which counted out one thousand grains of the sample. One thousand grains were then weighed on the laboratory scale. Measurement was performed in triplicate each year.

\subsection{Mashing Procedure-Production of Congress Worts from Naked and Hulled Oat Malts}

Congress worts were produced in the automated laboratory mashing machine (LB Electronic, Lochner Labor and Technik, Berching, Germany) according to the Analytica EBC method 4.5.1 [28]. Wort, after filtration, was collected for analyses. Congress worts from naked oat malt and hulled oat malt were prepared in duplicate each year.

\subsection{Analyses of the Worts during the Congress Mashing Regime}

All worts acquired in this study were assessed with the same methods.

\subsubsection{Saccharification Time}

Saccharification time was assessed by the Analytica EBC 4.5.1 method [28]. A duration of $10 \mathrm{~min}$ after adding water at a temperature of $70{ }^{\circ} \mathrm{C}$ to the mashes, measurement of saccharification time was started, and iodine tests were performed in 5 min intervals. If the iodine solution did not turn the mash blue, it meant that full saccharification of the starch occurred, and value of saccharification time was noted. The last tests were performed in the interval of 55 to $60 \mathrm{~min}$ of mashing at a temperature of $70^{\circ} \mathrm{C}$.

\subsubsection{Wort $\mathrm{pH}$}

Wort $\mathrm{pH}$ was assessed using a $\mathrm{pH}$ meter (MP220, Mettler Toledo, Columbus, $\mathrm{OH}$, USA) in worts collected after the filtration process. The temperature of the tested sample was $20^{\circ} \mathrm{C}$. Measurement was performed in triplicate for each wort sample (total of six measurements per one year per one type of malt), which was then averaged to one value per wort.

\subsubsection{Wort Extract Content}

The extract content of the worts was assessed with the use of densimeter (DMA 35, Anton Paar, Graz, Austria) in filtered congress wort with temperature adjusted to $20^{\circ} \mathrm{C}$. Measurements were performed in triplicate for each wort sample (total of six measurements per one year per one type of malt), which was then averaged to one value per wort.

\subsubsection{Wort Filtration Time}

Analysis of the wort filtration time was performed by the Analytica EBC 4.5.1. method [28].

\subsubsection{Wort Volume}

Wort volume was recorded from the scale of the graduated cylinder after the filtration process.

\subsection{Statistical Analysis}

All results were represented as mean \pm standard deviation. The focus of the conducted study was mainly on the assessment of differences between varieties and nitrogen fertilization on malting quality of the oats; therefore, data were averaged across all three years using values acquired in different years as repetitions. Two-way ANOVA, using the Fisher test $(\alpha=0.05)$, was performed to determine whether the oat variety or nitrogen fertilization had an impact on the parameters of the grain and malt. 


\section{Results}

The average yield of the oat varieties throughout the time of the study is given in Table 2 (results are based on the yield from each of the research plots).

Table 2. Average yield of the tested hulled and naked oat varieties throughout the study.

\begin{tabular}{lcccccc}
\hline & $\begin{array}{c}\text { Nitrogen } \\
\text { Fertilization } \\
\text { [kg N/ha] }\end{array}$ & $\begin{array}{c}\text { Amant } \\
\text { Grain } \\
\text { Yield } \\
\text { [t/ha] }\end{array}$ & $\begin{array}{c}\text { Maczo } \\
\text { Grain } \\
\text { Yield } \\
\text { [t/ha] }\end{array}$ & $\begin{array}{c}\text { Siwek } \\
\text { Grain } \\
\text { Yield } \\
\text { [t/ha] }\end{array}$ & $\begin{array}{c}\text { Polar } \\
\text { Grain } \\
\text { Yield } \\
\text { [t/ha] }\end{array}$ & $\begin{array}{c}\text { Kozak } \\
\text { Grain } \\
\text { Yield } \\
\text { [t/ha] }\end{array}$ \\
\hline 2018 & 40 & 4.490 & 4.865 & 5.328 & 3.603 & 5.488 \\
2018 & 60 & 4.390 & 4.285 & 5.023 & 3.333 & 5.667 \\
2018 & 80 & 4.548 & 4.563 & 5.383 & 3.623 & 5.892 \\
Average for 2018 & 4.476 & 4.571 & 5.244 & 3.519 & 5.682 \\
2019 & 40 & 3.668 & 3.513 & 3.968 & 3.375 & 4.772 \\
2019 & 60 & 4.023 & 3.473 & 4.203 & 4.003 & 5.284 \\
2019 & 80 & 4.150 & 3.645 & 4.215 & 4.060 & 5.309 \\
Average for 2019 & 3.947 & 3.543 & 4.128 & 3.813 & 5.122 \\
2020 & 40 & 5.268 & 4.550 & 4.205 & 5.120 & 7.408 \\
2020 & 60 & 5.390 & 4.730 & 4.195 & 5.173 & 7.765 \\
2020 & 80 & 5.440 & 4.743 & 4.640 & 5.208 & 7.839 \\
\multicolumn{2}{l}{ Average for 2020} & 5.366 & 4.674 & 4.347 & 5.167 & 7.671 \\
\hline
\end{tabular}

3.1. Analysis of the Naked Oat Grains, the Hulled Oat Grains, the Naked Oat Malts and the Hulled Oat Malts

\subsubsection{Basic Properties of the Hulled Oat and Naked Oat Grains}

Averaged protein content, starch content, moisture and thousand grain weight of the analysed naked oat varieties (Amant, Maczo, Polar and Siwek) and the hulled oat variety (Kozak) from the growing seasons of 2018, 2019 and 2020 are shown in Table 3.

Table 3. Averaged protein content, starch content, moisture and thousand grain weight of the naked oat varieties and hulled oat variety grains.

\begin{tabular}{ccccc}
\hline Sample & $\begin{array}{c}\text { Protein Content } \\
{[\% \boldsymbol{w} / \boldsymbol{w} ; \mathbf{d} . \mathbf{m} .]^{\mathbf{1}}}\end{array}$ & $\begin{array}{c}\text { Starch Content } \\
{[\% \boldsymbol{w} / \boldsymbol{w} ; \mathbf{d} . \mathbf{m} .]}\end{array}$ & $\begin{array}{c}\text { Moisture } \\
{[\% \boldsymbol{w} / \boldsymbol{w}]}\end{array}$ & TGW [g] \\
\hline K40G & $15.20 \pm 0.53 \mathrm{~b}$ & $55.43 \pm 1.47 \mathrm{ab}$ & $9.53 \pm 0.22 \mathrm{ab}$ & $24.23 \pm 0.50 \mathrm{abc}$ \\
K60G & $14.60 \pm 0.48 \mathrm{bc}$ & $55.67 \pm 1.37 \mathrm{ab}$ & $9.50 \pm 0.19 \mathrm{ab}$ & $25.22 \pm 0.44 \mathrm{a}$ \\
K80G & $13.97 \pm 0.26 \mathrm{c}$ & $55.87 \pm 1.20 \mathrm{ab}$ & $9.60 \pm 0.18 \mathrm{ab}$ & $24.83 \pm 0.49 \mathrm{ab}$ \\
A40G & $15.60 \pm 0.70 \mathrm{~b}$ & $52.20 \pm 2.70 \mathrm{~cd}$ & $8.90 \pm 0.15 \mathrm{~d}$ & $22.00 \pm 0.69 \mathrm{cdef}$ \\
A60G & $15.60 \pm 0.54 \mathrm{~b}$ & $52.63 \pm 2.48 \mathrm{~cd}$ & $9.37 \pm 0.21 \mathrm{abcd}$ & $21.63 \pm 0.55 \mathrm{cdef}$ \\
A80G & $16.07 \pm 0.52 \mathrm{a}$ & $51.63 \pm 2.78 \mathrm{~d}$ & $9.67 \pm 0.27 \mathrm{a}$ & $22.23 \pm 0.42 \mathrm{bcde}$ \\
M40G & $15.37 \pm 0.72 \mathrm{~b}$ & $54.10 \pm 2.18 \mathrm{bc}$ & $9.17 \pm 0.15 \mathrm{bcd}$ & $20.38 \pm 1.48 \mathrm{ef}$ \\
M60G & $15.27 \pm 0.82 \mathrm{~b}$ & $54.70 \pm 1.71 \mathrm{bc}$ & $9.40 \pm 0.10 \mathrm{abc}$ & $20.43 \pm 1.38 \mathrm{ef}$ \\
M80G & $15.77 \pm 0.69 \mathrm{ab}$ & $54.77 \pm 2.02 \mathrm{bc}$ & $9.13 \pm 0.12 \mathrm{bcd}$ & $23.09 \pm 1.93 \mathrm{abcd}$ \\
P40G & $15.33 \pm 1.21 \mathrm{~b}$ & $53.63 \pm 2.40 \mathrm{bcd}$ & $9.67 \pm 0.23 \mathrm{a}$ & $23.81 \pm 1.54 \mathrm{abc}$ \\
P60G & $15.63 \pm 1.22 \mathrm{ab}$ & $53.57 \pm 2.35 \mathrm{bcd}$ & $9.30 \pm 0.10 \mathrm{abcd}$ & $23.75 \pm 0.41 \mathrm{abc}$ \\
P80G & $15.20 \pm 0.90 \mathrm{~b}$ & $53.27 \pm 2.40 \mathrm{bcd}$ & $9.27 \pm 0.06 \mathrm{abcd}$ & $22.74 \pm 0.44 \mathrm{abcde}$ \\
S40G & $16.00 \pm 0.51 \mathrm{a}$ & $52.60 \pm 2.70 \mathrm{~cd}$ & $9.00 \pm 0.15 \mathrm{~cd}$ & $19.92 \pm 0.48 \mathrm{f}$ \\
S60G & $16.23 \pm 0.35 \mathrm{a}$ & $53.63 \pm 2.31 \mathrm{bcd}$ & $8.97 \pm 0.15 \mathrm{~cd}$ & $20.79 \pm 0.53 \mathrm{def}$ \\
S80G & $16.30 \pm 0.26 \mathrm{a}$ & $53.40 \pm 2.43 \mathrm{bcd}$ & $9.00 \pm 0.08 \mathrm{~cd}$ & $21.00 \pm 0.87 \mathrm{def}$ \\
\hline
\end{tabular}

${ }^{1}$ Values are expressed as mean $(n=9) \pm$ standard deviation. Mean values with different letters $(\mathrm{a}, \mathrm{b}, \ldots, \mathrm{f})$ within the same column are statistically different $(\alpha=0.05)$ according to the Fisher test.

Protein content in the grains was in the range of $13.97-16.30 \%$. The highest protein content was found in the naked oat grain of Siwek variety (S40G, S60G, S80G) and in the grain of Amant variety (A80G). The lowest protein content was determined in the grain of hulled oat cultivar Kozak (K80G).

The starch content in hulled and naked oat grains ranged from 51.63\% (A80G) to 55.87\% (K80G). The humidity of the tested grains ranged from $8.90 \%$ (A40G) to $9.67 \%$ (A80G). 
The starch content in hulled and naked oat grains was determined to be in the range from $51.63 \%$, for A $80 \mathrm{G}$, to $55.87 \%$, for K80G. The humidity of the tested grains ranged from $8.90 \%$, for A40G, to $9.67 \%$, for A80G. The thousand grain weight ranged from $19.42 \mathrm{~g}$, for $\mathrm{S} 40 \mathrm{G}$, to $25.22 \mathrm{~g}$, for K60G.

\subsubsection{Basic Properties of the Hulled Oat and Naked Oat Malts}

The basic parameters of malts from naked oats and hulled oats are as follows: total protein content, soluble protein content, extractivity, moisture, Kolbach index and thousand kernel mass-these are shown in Table 4.

Table 4. Averaged protein content, soluble protein content, Kolbach index, extractivity, moisture and thousand grain weight of the naked oat varieties and hulled oat variety.

\begin{tabular}{|c|c|c|c|c|c|c|}
\hline Sample & $\begin{array}{l}\text { Protein Content } \\
{[\% w / w ; \mathrm{d} . \mathrm{m} .]^{1}}\end{array}$ & $\begin{array}{c}\text { Soluble Protein } \\
\text { Content [\% } w / w ; \text { d.m.] }\end{array}$ & Kolbach index & Extractivity [\%] & $\begin{array}{l}\text { Moisture } \\
{[\% w / w]}\end{array}$ & TGW [g] \\
\hline K40M & $10.43 \pm 0.24 \mathrm{e}$ & $4.70 \pm 0.27 b$ & $40.16 \pm 0.72$ ef & $81.07 \pm 0.09 \mathrm{~d}$ & $3.90 \pm 0.06 \mathrm{f}$ & $21.93 \pm 0.53 \mathrm{ab}$ \\
\hline K60M & $10.33 \pm 0.33 \mathrm{e}$ & $4.60 \pm 0.26 b$ & $41.07 \pm 0.32 \mathrm{def}$ & $81.27 \pm 0.07 \mathrm{~cd}$ & $4.10 \pm 0.10 \mathrm{f}$ & $22.14 \pm 0.62 \mathrm{a}$ \\
\hline K80M & $10.50 \pm 0.08 \mathrm{e}$ & $4.53 \pm 0.28 b$ & $39.06 \pm 0.96 \mathrm{f}$ & $81.63 \pm 0.22 \mathrm{abcd}$ & $3.90 \pm 0.06 \mathrm{f}$ & $21.59 \pm 0.54 \mathrm{ab}$ \\
\hline $\mathrm{A} 40 \mathrm{M}$ & $11.53 \pm 0.59 \mathrm{~cd}$ & $5.67 \pm 0.02 \mathrm{a}$ & $46.82 \pm 2.84 \mathrm{a}$ & $81.50 \pm 0.14 \mathrm{abcd}$ & $7.43 \pm 0.02 \mathrm{a}$ & $19.04 \pm 0.06 \mathrm{de}$ \\
\hline A60M & $11.97 \pm 0.33 \mathrm{bcd}$ & $5.63 \pm 0.02 \mathrm{a}$ & $45.45 \pm 1.64 \mathrm{ab}$ & $81.90 \pm 0.31 \mathrm{abc}$ & $6.73 \pm 0.18 b c$ & $19.89 \pm 0.06 \mathrm{~cd}$ \\
\hline A80M & $12.20 \pm 0.32 \mathrm{bc}$ & $5.63 \pm 0.02 \mathrm{a}$ & $44.51 \pm 1.39 \mathrm{abcd}$ & $81.83 \pm 0.30 \mathrm{abc}$ & $6.93 \pm 0.21 \mathrm{ab}$ & $20.87 \pm 0.02 b c$ \\
\hline M40M & $12.10 \pm 0.48 b c$ & $5.63 \pm 0.02 \mathrm{a}$ & $45.21 \pm 2.03 \mathrm{abc}$ & $81.93 \pm 0.39 \mathrm{ab}$ & $6.57 \pm 0.22 b c$ & $16.64 \pm 0.31 \mathrm{~g}$ \\
\hline M60M & $12.27 \pm 0.52 \mathrm{bc}$ & $5.57 \pm 0.04 \mathrm{a}$ & $44.03 \pm 1.73$ abcde & $81.97 \pm 0.39 \mathrm{a}$ & $6.00 \pm 0.18 \mathrm{de}$ & $17.21 \pm 0.33 \mathrm{fg}$ \\
\hline M80M & $12.60 \pm 0.53 \mathrm{ab}$ & $5.53 \pm 0.06 \mathrm{a}$ & $43.71 \pm 1.58$ abcde & $81.67 \pm 0.22 \mathrm{abcd}$ & $6.03 \pm 0.14 \mathrm{de}$ & $18.02 \pm 0.59$ ef \\
\hline P40M & $12.70 \pm 0.30 \mathrm{ab}$ & $5.67 \pm 0.02 \mathrm{a}$ & $43.04 \pm 1.02$ abcde & $81.29 \pm 0.09$ cde & $6.63 \pm 0.12 \mathrm{bc}$ & $20.45 \pm 0.52 b c$ \\
\hline P60M & $12.73 \pm 0.19 \mathrm{ab}$ & $5.53 \pm 0.03 \mathrm{a}$ & $41.66 \pm 0.17$ bcdef & $81.30 \pm 0.07$ cde & $6.30 \pm 0.21 \mathrm{cde}$ & $22.11 \pm 0.19 a$ \\
\hline P80M & $13.33 \pm 0.17 \mathrm{a}$ & $5.60 \pm 0.03 \mathrm{a}$ & $41.34 \pm 0.24$ cdef & $81.32 \pm 0.08$ cde & $6.63 \pm 0.29 b c$ & $21.58 \pm 0.13 \mathrm{ab}$ \\
\hline S40M & $12.30 \pm 0.20 b c$ & $5.57 \pm 0.02 \mathrm{a}$ & $43.45 \pm 0.83$ abcde & $81.87 \pm 0.22 \mathrm{abc}$ & $6.00 \pm 0.31 \mathrm{de}$ & $19.78 \pm 0.58 \mathrm{~cd}$ \\
\hline S60M & $12.07 \pm 0.23 \mathrm{bcd}$ & $5.60 \pm 0.01 \mathrm{a}$ & $44.66 \pm 1.27 \mathrm{abcd}$ & $81.70 \pm 0.20 \mathrm{abcd}$ & $6.37 \pm 0.13 \mathrm{~cd}$ & $20.66 \pm 0.45 b c$ \\
\hline S80M & $11.10 \pm 0.16 \mathrm{de}$ & $5.37 \pm 0.07 \mathrm{a}$ & $45.18 \pm 1.49 \mathrm{abc}$ & $81.73 \pm 0.19 \mathrm{abc}$ & $5.83 \pm 0.15 \mathrm{e}$ & $19.92 \pm 0.67 \mathrm{~cd}$ \\
\hline
\end{tabular}

${ }^{1}$ Values are expressed as mean $(n=9) \pm$ standard deviation. Mean values with different letters $(a, b, \ldots, g)$ within the same column are statistically different $(\alpha=0.05)$ according to the Fisher test.

The protein content in malts was lower than in grains and ranged from $10.33 \%$ to $12.70 \%$. The lowest protein content was determined in the K40M, K60M and K80M (respectively: $10.43 \%, 10.33 \%$ and $10.50 \%$ ). The highest protein content was determined in P80M malt, where it was equal to $13.33 \%$. The soluble protein content in the malts was lowest in K80M (4.53\%) and highest in A40M and P40M (5.67\%). The Kolbach index, indicating the degree of malt protein modification, ranged from 39.06 to $46.82 \%$ [29,30]. The lowest value of Kolbach index was obtained K40M (39.06\%), while the highest Kolbach index was obtained by A40M (46.82\%). The extractivity of all tested malts was similar and ranged from $81.07 \%$, for $\mathrm{K} 40 \mathrm{M}$, to $81.97 \%$, for M60M. The lowest moisture content was determined in K40M and K80M (3.90\%) and highest in A40M (7.43\%). Produced malts differed significantly in the TGW, which was smaller than that of unmalted seeds, ranging from $16.64 \mathrm{~g}$, for M40M, to $22.14 \mathrm{~g}$, for K60M.

\subsubsection{Technological Parameters of the Naked Oat and Hulled Oat Malts}

For the analysis of technological parameters of malts from the naked and hulled oat grains, the congress mashing method, described by the Analytica EBC, was used [28]. Analysed technological parameters included the following: saccharification time, wort $\mathrm{pH}$, wort extract content, wort filtration time and wort volume. Data are shown in Table 5. 
Table 5. Properties of the malts prepared from the hulled oat grains and naked oat grains.

\begin{tabular}{|c|c|c|c|c|c|}
\hline Sample & $\begin{array}{l}\text { Saccharification } \\
\text { Time [min] }{ }^{1}\end{array}$ & Wort pH & $\begin{array}{c}\text { Wort Extract } \\
\text { Content }[\% w / w]\end{array}$ & $\begin{array}{l}\text { Wort Filtration } \\
\text { Time [min] }\end{array}$ & Wort Volume [mL] \\
\hline K40W & $26.67 \pm 4.64 \mathrm{a}$ & $5.58 \pm 0.22 \mathrm{a}$ & $5.93 \pm 0.12 c$ & $105 \pm 7.50 \mathrm{~b}$ & $223.33 \pm 36.40 \mathrm{a}$ \\
\hline K60W & $26.67 \pm 5.83 \mathrm{a}$ & $5.55 \pm 0.01 \mathrm{a}$ & $6.23 \pm 0.20 c$ & $106.67 \pm 6.67 \mathrm{ab}$ & $228.33 \pm 34.83 \mathrm{a}$ \\
\hline K80W & $26.67 \pm 5.83 \mathrm{a}$ & $5.34 \pm 0.13 b$ & $6.13 \pm 0.23 c$ & $110 \pm 5 a$ & $221.67 \pm 38.03 \mathrm{a}$ \\
\hline A40W & $21.67 \pm 3.33 \mathrm{abc}$ & $5.05 \pm 0.13 c$ & $7.12 \pm 0.03 b$ & $110 \pm 5 a$ & $168.33 \pm 38.74 c$ \\
\hline A60W & $23.33 \pm 3.00 \mathrm{ab}$ & $5.03 \pm 0.12 c$ & $7.14 \pm 0.04 b$ & $110 \pm 5 a$ & $158.33 \pm 31.44 \mathrm{~d}$ \\
\hline A80W & $23.33 \pm 3.00 \mathrm{ab}$ & $5.04 \pm 0.10 c$ & $7.15 \pm 0.05 b$ & $108.33 \pm 5.83 \mathrm{ab}$ & $156.67 \pm 31.37 \mathrm{~d}$ \\
\hline M40W & $13.33 \pm 0.83 \mathrm{~d}$ & $5.00 \pm 0.11 \mathrm{c}$ & $7.29 \pm 0.08 \mathrm{ab}$ & $110 \pm 5 a$ & $171.67 \pm 38.58 c$ \\
\hline M60W & $15 \mathrm{~cd}$ & $4.98 \pm 0.11 c$ & $7.30 \pm 0.08 \mathrm{ab}$ & $108.33 \pm 5.83 \mathrm{ab}$ & $175 \pm 40.10 \mathrm{bc}$ \\
\hline M80W & $16.67 \pm 0.83 \mathrm{bcd}$ & $4.99 \pm 0.12 c$ & $7.29 \pm 0.07 \mathrm{ab}$ & $108.33 \pm 5.83 \mathrm{ab}$ & $168.33 \pm 41.69 c$ \\
\hline P40W & $21.67 \pm 2.20 \mathrm{abc}$ & $4.99 \pm 0.08 c$ & $7.56 \pm 0.08 \mathrm{a}$ & $103.33 \pm 8.33 \mathrm{~b}$ & $155 \pm 45.21 \mathrm{~d}$ \\
\hline P60W & $16.67 \pm 0.83 \mathrm{bcd}$ & $4.99 \pm 0.08 c$ & $7.48 \pm 0.14 \mathrm{a}$ & $110 \pm 5 a$ & $203.33 \pm 39.06 \mathrm{ab}$ \\
\hline P80W & $16.67 \pm 0.83 \mathrm{bcd}$ & $5.00 \pm 0.08 c$ & $7.32 \pm 0.12 \mathrm{ab}$ & $106.67 \pm 6.67 \mathrm{ab}$ & $156.67 \pm 41.06 \mathrm{~d}$ \\
\hline S40W & $13.33 \pm 0.83 \mathrm{~d}$ & $4.98 \pm 0.22 c$ & $7.04 \pm 0.11 b$ & $96.67 \pm 11.67 c$ & $191.67 \pm 40.68 b$ \\
\hline S60W & $13.33 \pm 0.83 \mathrm{~d}$ & $4.98 \pm 0.10 c$ & $7.03 \pm 0.07 b$ & $110 \pm 5 a$ & $191.67 \pm 36.86 b$ \\
\hline S80W & $11.67 \pm 0.83 \mathrm{~d}$ & $4.96 \pm 0.10 c$ & $7.02 \pm 0.10 b$ & $113.33 \pm 3.33 \mathrm{a}$ & $193.33 \pm 37.03 b$ \\
\hline
\end{tabular}

${ }^{1}$ Values are expressed as mean $(n=6) \pm$ standard deviation. Mean values with different letters $(\mathrm{a}, \mathrm{b}, \mathrm{c}, \mathrm{d})$ within the same column are statistically different $(\alpha=0.05)$ according to the Fisher test.

The analysis of the congress worts showed a significant differentiation between the technological parameters of the tested malts. The saccharification time of the mashes turned out to be the shortest for naked oat malts of the Siwek variety (S40W, S60W and S80W) and ranged from 11.67 to $13.33 \mathrm{~min}$ and was similar to the saccharification time that should be achieved by Pilsner-type barley malts [28,29]. Mashes from hulled oats became saccharified in an excessively long time, amounting to an average of $26.67 \mathrm{~min}$, regardless of the degree of fertilization of oat plants. Standard, Pilsner-type barley malts ought to saccharify within 20 min [29]. Malts from naked oat of Amant variety (A40W, A60W and A80W) saccharified after the longest, non-normative time, $21.67,23.33$ and $23.33 \mathrm{~min}$, respectively.

The $\mathrm{pH}$ of naked oat worts was very similar, regardless of the variety and the degree of nitrogen fertilization used (from 4.96 for S80W to 5.05 for A40W), while K40W and K60W hulled oat wort had a significantly higher $\mathrm{pH}$ (5.58 and 5.55). Wort produced from malt from hulled oat of the Kozak variety, with the highest level of nitrogen fertilization (K80W) characterised with lower $\mathrm{pH}$ of 5.34 .

Typical congress worts made of pilsner-type barley malts contain between $8 \%$ and $9 \%$ of the extract [29]. The highest content of the extract was determined in the wort obtained from malt from naked oat P40W and P60W, which amounted to $7.54 \%$ and $7.48 \%$. The extract content in the wort of naked oat of Maczo cultivar was 7.29-7.30\%; of naked oat variety Amant 7.12-7.15\%; of naked oat variety Siwek 7.02-7.04\%. Wort produced from hulled oat malts had lower extract content, in the range of 5.93-6.23\%.

All of the worts were characterised with long filtration time, from $96.33 \mathrm{~min}$, for S40W, to $113.33 \mathrm{~min}$, for S80W [28].

The largest volume of the congress laboratory wort was determined in the $\mathrm{K} 40 \mathrm{~W}$, K60W and K80W tests. It ranged from 221.67 to $228.33 \mathrm{~mL}$. The P40W, P80W, A60W and A80W malts were characterized by the smallest wort volume, in the range of 155-158.33 mL. Among the samples made from naked oat malts, S40W, S60W and S80W worts had the largest volumes, in the range of 191.67-193.33 mL.

\section{Discussion}

\subsection{Analysis of the Hulled and Covered Oat Grains and Hulled and Naked Oat Malts 4.1.1. Basic Properties of the Hulled Oat and Naked Oat Grains}

One of the most important features of the typical malting material, which is barley grain, is its protein content, which should be below 11.5\% [2,29]. Higher protein content in barley grains used for the production of malt is unfavourable, as it most often causes unfavourable changes in the parameters of the produced beer $[2,29,31,32]$. 
Naked oat grain is characterized, from the point of view of the requirements for malting barley, with an excessively high protein content, which may equal to as much as $20 \%$ of the grain weight [33-36]. Hulled oats have a lower protein content than naked oats, in the range of $11-15 \%$, which in most cases exceeds the maximum protein content recommended for malting barley grains intended for the production of Pilsner-type malt. The grain of malting barley, with a protein content of $9-11.5 \%$, contains sufficient amounts of proteins necessary to produce the desired amount of amylolytic, proteolytic and other enzymes used in the production of beer wort [29,37-39]. Grains of naked oat, which are not widely analysed in terms of the production of malt and beer wort, have not been tested as the grains of barley have, and there is a chance that the higher protein content in the raw material intended for malting will not excessively interfere with the process of obtaining beer wort. The only comparison that can be made is with regard to the brewing process with the hulled oat, because hulled oat malts (with the need to modify the mashing process), according to Klose et al., enables the production of oat beer from $100 \%$ oat malt [6]. The acquired results show that the level of nitrogen fertilization of naked oat plants with 40 to $80 \mathrm{~kg}$ of nitrogen per hectare has an impact on the accumulation of protein in kernels. The dose of $80 \mathrm{~kg}$ of nitrogen per hectare had a significant effect on increasing the protein content in grains of Amant and Maczo cultivars. However, the dose of $80 \mathrm{~kg}$ of nitrogen per hectare, in the case of Kozak hulled oat, reduced the protein content.

The content of starch in oat grain is an important parameter, both in malting and in the process of obtaining beer wort. Starch is a complex sugar made of glucose molecules. In typical brewing technology, starch is broken down by the amylolytic enzymes present in the malt into sugars that can be fermented by yeast, such as glucose, maltose and maltotriose [2,29]. It is important for grain intended for malting to contain as much starch as possible. The content of starch in barley grain can be from $45.7 \%$ to $70 \%$, while, according to Kunze, barley grain intended for malting should contain $52-67 \%$ starch $[12,39,40]$. The starch content in naked oat grains intended for malting was within the barley malting standards, with the exception of the A80G sample, which, apart from the lowest starch content, was also characterized by the highest protein content. These factors might indicate that cultivation of Amant naked oat grain with the addition of $80 \mathrm{~kg}$ of nitrogen per hectare might result in a raw material which is not suitable for the malting and brewing industry.

The thousand grain weight is an important parameter for cereal grains, whether or not they are intended to be used as a malting material [41-44]. When assessing grain as a raw material for the production of malt, grain with a large thousand grain weight is preferable, as maltsters primarily want a high proportion of starch, which is accumulated in the endosperm of the grain, and not in the pericarp and seed coat. Along with the increase in grain size, the share of fruit-seed cover in the weight of malt decreases $[2,45,46]$.

Among the evaluated grains, oat grains from plants fertilized with a dose of $60 \mathrm{~kg}$ of nitrogen per hectare were characterized by the highest weight. Most of the grains of the naked oats were characterized by a lower TGW than those of the Kozak variety, with the exception of the Polar variety and M80G grains. However, all the examined grains were characterized by a lower, almost by a half, value of the weight of a thousand grains when compared with the typical value of this feature for barley, the amounts of which are typically in the range of $30-44 \mathrm{~g}[2,47,48]$.

\subsubsection{Basic Properties of the Hulled Oat Malts and Naked Oat Malts}

The protein content in malts prepared in laboratory conditions was lower than in the grains. This is a typical phenomenon that occurs during the malting process, as the malts lose protein compounds during the process of soaking and germination of the grain and the drying and de-germination of the malts [2]. After the drying process, the malt from naked oats, compared with the hulled oats, during germination, loses not only the germinal roots, but also the sprouts, which contain a lot of protein compounds [49,50].

The protein content in the malt cannot be too high, as the proteins present in the grain may hinder the enzymatic hydrolysis of starch by physically blocking the access to it by 
enzymes (including amylolytic) [51,52]. Malt as a raw material for the production of wort under certain mashing conditions must not contain too much or too little protein, because the products of protein hydrolysis are necessary, inter alia, for the proper multiplication and physiological state of Saccharomyces cerevisiae yeast and the course of ethanol fermentation of the beer $[29,53]$.

Proteins present in the malt are broken down by proteolytic enzymes during the mashing process to forms, such as, for example, free amino acids, that can be used by yeast; therefore, the use of raw material that is too low in protein may adversely affect the fermentation process of the wort [54-56]. In addition, too low protein content in the wort may contribute to the deterioration of the stability and quality of the foam of the produced beer. Excessive content of protein enzymatic hydrolysis products, especially high-molecular ones, deteriorates the clarity of beer and facilitates the formation of various types of turbidity $[29,57,58]$.

Typical barley Pilsner malt ought to contain up to $11.5 \%$ of protein [2,28]. Among the malts produced in this study, only the samples K40M, K60M, K80M and S80M were characterized by the protein content appropriate for Pilsner malt. In the brewing technology, barley malts of a type other than Pilsner type, such as pale ale, Viennese or Munich malt, may be characterized by a higher protein content, amounting to $12 \%$, respectively, and up to $12.5 \%$ in the case of Munich malt [2]. Almost all of the analysed malts were characterized with protein content within this range, which indicates that the excessive protein content in the grain of naked oats and hulled oats does not impede the production of malts with the proper protein content. Only the malts from Polar variety and Maczo variety fertilized with a dose of $80 \mathrm{~kg}$ of nitrogen per hectare were characterized by an excessively high protein content. The topic of the impact of fertilizing naked oat plants with nitrogen on the total protein content in grain intended for malting can be solved by developing a cultivation and fertilization technology analogically to the cultivation recommendations used in the cultivation of malting barley $[2,29,59,60]$.

All naked oat malts were characterized by a similar content of soluble protein, which was higher than the content of soluble protein in malts prepared from hulled oats; however, this is not an unusual result, because the hulled oat malt had the lowest total protein content. The parameter that describes the ratio of the soluble protein content to the total protein content is the Kolbach index, which indicates the percentage of proteins that have undergone enzymatic hydrolysis during the malting and mashing process and may be dissolved in the wort [28,29]. Too low Kolbach index usually indicates insufficient activity of proteolytic enzymes present in the produced malt [60]. The brewing technology usually uses malts with Kolbach index above 35\% and below 45\% [29]. Malt with a Kolbach number above $41 \%$ is described in malting terminology as having "very good proteolytic relaxation" and is well seen in the brewing industry $[60,61]$. All naked oat malts had Kolbach number exceeding 41\%. A40M, A60M and S80M malts were characterized by excessive proteolytic hydrolysis, exceeding $45 \%$, which may deteriorate the foaminess of the beer produced with the use of these malts [29].

Extractivity of the malt is a parameter which determines which part of the malt substances can be dissolved in the wort as a result of the mashing process [29]. The extractivity of the malts produced in this study was very similar, regardless of the oat variety and the level of its nitrogen fertilization, and differed by a maximum of $0.9 \%$ (between the K40M sample with the lowest extractivity $81.07 \%$ and M60M with the highest extractivity $81.97 \%$ ). The minimal extractivity for Pilsner barley malts is $80 \%$ [2,29]. All oat malts produced in this study were characterized by an extractivity higher than $80 \%$; therefore, it is not a parameter that could indicate that naked oats and hulled oats of the studied varieties are not suitable for the production of Pilsner type malt.

The moisture content of Pilsner barley malts is usually up to 5\% [2]. This facilitates the transport of raw material, reduces the load on the equipment used for the production of the wort, ensures resistance of the malt to fungal diseases and reduces the development of pests $[13,62-65]$. Only malt from the hulled variety was characterized by a moisture content 
in the range of up to $5 \%$. Both oat and barley hulls have a lower tendency to retain water than the endosperm of the grain, which may result in higher moisture content of naked oat malts, which lack the hull $[66,67]$. In the malting technology, malt from grains without hulls, such as rye or wheat, also possess higher moisture content than malts from hulled barley [2]. The differences in the water content in naked oat malts may also result from the content of proteins and non-starch polysaccharides in the grain and their influence on the process of binding the water, which might hinder water evaporation during drying [67-70].

Analysis of TGW showed that during malting, both naked oats and hulled oats lose about 1 to $3 \mathrm{~g}$ of weight, which is a phenomenon caused by the consumption of reserve substances in the process of aerobic respiration and separation from the malt in the process of germinating, the sprout and germinal roots, as well as loses of water during the grain drying [2].

\subsection{Analysis of Technological Parameters of Naked and Hulled Oat Malts and Worts Produced from Malts during the Congress Mashing}

The technological parameters of the malts made from the grains of hulled oats and naked oats were determined on the basis of the results obtained during the most common and routinely used method of malt analysis, which is the production of laboratory wort by mashing malts by the congress method, which analyses key parameters of the malts which are crucial for the brewing industry [29].

The saccharification time is a parameter that determines the activity of amylolytic enzymes in the produced malt, which should hydrolyse starch present in the malt and produce fermentable sugars, such as glucose, maltose and maltotriose [29]. If the malt fails to saccharify up to 20 min during the congress mashing, this indicates insufficient activity of these enzymes or the presence of factors that prevent physical access of amylolytic enzymes to starch. Excessive saccharification time (too long) in brewing mashes occurs most often as a result of incomplete starch gelatinization [2,29].

All malts produced in this experiment saccharified completely. The longest saccharification time was characteristic for hulled oat grains. The degree of fertilization of the oat plants had no significant effect on the saccharification time of the mash. Naked oat malt, Siwek variety, was characterized by saccharification time ranging from 11.67 to $13.33 \mathrm{~min}$. The next malts, which quickly saccharified during mashing were those of the Maczo variety, had a saccharification time from 13.33 to $16.67 \mathrm{~min}$. Malts obtained from the Amant naked oat variety (21.67-23.33 $\mathrm{min}$ ) were characterized by the longest saccharification time.

The effect of nitrogen fertilization in oats plants on the saccharification time is interesting. Increased nitrogen dose from $40 \mathrm{~kg}$ to $80 \mathrm{~kg}$ of nitrogen per hectare extended the saccharification time of the mash from malts from the Maczo and Amant varieties and reduced the saccharification time of the mash from the Siwek and Polar varieties. This indicates the possibility of the presence of a factor other than the protein content in grain, which affects the saccharification time of mash obtained from oat malts of various varieties. This requires further research.

The $\mathrm{pH}$ of the wort in brewing technology is usually analysed to detect whether wort $\mathrm{pH}$ is optimal for the activity if enzymes present in the barley malts [2,29]. The results obtained in this experiment show that the degree of nitrogen fertilization of the plants and the naked oat variety did not have a significant effect on the $\mathrm{pH}$ variability of the congress wort, which was about $5.00 \mathrm{pH}$ units. The $\mathrm{pH}$ of the hulled oat wort was higher, ranging from 5.34 to 5.58 . K80M malt wort with a lower $\mathrm{pH}$ (5.34) indicates that fertilizing $80 \mathrm{~kg}$ of nitrogen per hectare reduces the $\mathrm{pH}$ value for hulled oats of Kozak variety. It is worth noting that the optimal $\mathrm{pH}$ for most barley malt enzymes is 5.50, which indicates that K40M and K60M malt could be freely mixed with barley malt, without disturbing the activity of enzymes present in Pilsner-type barley malt [29]. Malts with a lower pH could be used as an additive to the mash with lower quality barley malts, characterized with too high a $\mathrm{pH}$ value.

The analysis of the extract content in congress wort shows that worts from naked oat malts and hulled oat malts are characterized by a lower extract content compared 
with typical congress worts made of barley malt, in which the extract content ranges from $8.1 \%$ to $9.0 \%[2,11,59,71]$. None of the worts obtained in this study fell within this value range. The lowest content of the extract was determined in the worts from hulled oat malts, amounting to $5.93-6.23 \%$, which is $66-75 \%$ of the value achieved by the standard congress wort produced from Pilsner barley malt. Wort produced from naked oats had a higher extract content than from hulled oats. The wort from the Polar variety obtained the highest $(7.32-7.56 \%)$. This may indicate the fact that the husk of hulled oats contains substances that interact with the ingredients formed during mashing and bind the extract components into various complexes that remain in the spent grain after the filtration process $[2,29,39]$. The fact that naked oat wort has a higher extract content compared with hulled oat is not surprising - the husk of the grain usually does not contain substances that are largely extracted into the wort [2,72-74]. The reason why the extract content of the tested wort is lower than the extract content in typical barley wort, despite the similar protein and starch content to barley grains, requires an explanation; however, the conclusion that can be drawn from the evaluation of congress wort is that the degree of fertilization of naked oat and hulled oat plants did not have a large influence on the extract content in the wort. The only exception to this rule is malt from naked oats of the Polar variety. In wort made of malt from grains of this variety, a slight decrease in the extract content can be observed with an increase in the nitrogen dose used for plant fertilization.

The wort filtration time is an extremely important parameter in brewing technology, as shortening the filtration time allows producers to accelerate entire beer production process [29]. In the analysis of congress wort, a filtration time of less than 60 min is referred to as "normal" and greater than $60 \mathrm{~min}$ is described as "slow". The maximum allowable filtration time during this analysis is $120 \mathrm{~min}$ [28]. All hulled and naked oat malts were characterized by a slow filtration time, which may be a significant technological problem in the production of wort and beers from this raw material. Extended filtration time of wort may result from high concentration of compounds, such as beta-glucans, non-hydrolysed proteins, phenolic compounds, various types of insoluble polysaccharides or hemicelluloses $[2,29,75]$. The dose of nitrogen fertilizer used during the cultivation of oat plants did not show a significant effect on the filtration time of worts from malts of the Amant and Maczo cultivars, while it significantly influenced the filtration time of wort from the Siwek cultivar. The S40M test had the shortest filtration time. These results may indicate that, for most naked oat malts (except for the Siwek variety), it is not the proteins (compounds most likely to be influenced by the nitrogen dose applied) that are the source of filtration difficulties. In the case of the Siwek variety, the situation is opposite-probably because the nitrogen compounds have a significant impact on the difficulties of the wort filtration process. The volume of the wort obtained by the mashing process varied considerably and, in each case, this was significantly smaller than the typical volume of congress wort obtained from Pilsner barley malt, which is usually in the range of 300-350 mL. It should be noted that in the mashing process it is important for producing the largest possible volume of the wort with the highest extract content [29]. It is worth noting that the wort with the lowest extract content, obtained from the K40W, K60W and K80W malts, had the highest volume, which means that the sum of substances extracted from the malt was greater than in the case of the wort with the smallest volume, such as A40W, A60W, A80W, P40W and P80W. The wort with the highest amount of extract and the highest volume of naked oat malts were found to be S40W, S60W, S80W and P60W. This may indicate that the Amant naked oat variety is characterized by the highest amounts of substances that bind water and impede filtration, such as, for example, beta-glucans or arabinoxylans [37]. The factor that seems to be more complicated to explain is that the samples from the same variety of naked oats (Polar) with a fertilizer of 40 and $80 \mathrm{~kg}$ of nitrogen per hectare causes the wort to be poorly filtered, while with a dose of $60 \mathrm{~kg}$ of nitrogen per hectare it is filtered the best of all the tested naked oat malts. The reason is most likely that the composition of proteins contained in grains of this variety and the study of its composition could bring interesting results in the future. 


\section{Conclusions}

The evaluation of the malting suitability of naked oat grains of Amant, Maczo, Polar and Siwek varieties and of the hulled Kozak variety was carried out on the basis of an analysis developed for the evaluation of malting barley grain and malts obtained from it using the congress mashing method. Overall, the assessment was positive, but showed technological problems at the stage of malt mashing and wort filtration. The grain of hulled oats of the Kozak variety and the grain of naked oats of the Amant, Maczo, Polar and Siwek varieties are characterized by malting suitability, allowing for the production of Pilsnertype malts from them. Malts of this type can be used in brewing technology and other, related branches of the food industry, despite the fact that they have worse technological parameters than typical Pilsner-type barley malts. The advantage of oat malts is the fact that they are gluten-free and rich in specific nutrients appreciated by the food industry. The use of various doses of nitrogen fertilizer during oat cultivation turned out to have an impact on significant technological parameters of the produced malts. However, the rather low wort volume combined with low wort extract of the congress worts produced from $100 \%$ naked oat malt show, that these malts in their current form could be used by the brewers and other food technologists rather as an adjunct, and not as the main part of the grain bill. Furthermore, naked oat malts could play a role as an additive, which could decrease the $\mathrm{pH}$ of the worts produced from barley malts, which are characterised with improper modification. However, results acquired in this study show that covered oat malts could are better than naked oat malts in the terms of the wort volume as well as wort $\mathrm{pH}$; however, Maczo and Siwek malts could possess good amylolytic properties. Furthermore, the low $\mathrm{pH}$ of the worts from naked oat malts shows that they might have promising potential as an adjunct which could decrease $\mathrm{pH}$ of the mash to the optimal levels, which might be an advantage in the brewing technologies using unmalted cereal adjuncts in the mashing process. The differences of oat malts compared with barley malts are so great that they indicate the need to develop methods other than congress mashing methods for the evaluation of malts from the naked oat grains as well as hulled oat grains. Further research about interesting properties and composition of naked oat malt, as, for example, beta-glucan content, might show that these malts could find viable place in the food industry.

Author Contributions: Conceptualization, J.B. and D.L.; methodology, J.B., J.K.-R. and A.G.; software, A.G.; validation, J.B., J.K.-R., D.L., J.G. and A.G.; formal analysis, J.B. and A.G.; investigation, J.B. and A.G.; resources, J.K.-R., D.L. and J.G.; data curation, J.B. and A.G.; writing-original draft preparation, J.B., D.L. and A.G.; writing-review and editing, J.B., J.K.-R., D.L. and A.G.; supervision, J.B., J.K.-R. and D.L.; project administration, J.B., J.K.-R. and D.L.; funding acquisition, J.B., J.K.-R., D.L. and J.G. All authors have read and agreed to the published version of the manuscript.

Funding: The studies have been supported by the Polish Ministry of Science and Higher Education within the statutory activity of the Institute of Soil Science and Plant Cultivation State Research Institute; task 2.40 Assessment of selected oat varieties in terms of suitability for brewing purposes.

Institutional Review Board Statement: Not applicable.

Informed Consent Statement: Not applicable.

Data Availability Statement: The data presented in the study are available in the study itself.

Conflicts of Interest: The authors declare no conflict of interest.

\section{References}

1. Bathgate, G.N. A review of malting and malt processing for whisky distillation. J. Inst. Brew. 2016, 122, 197-211. [CrossRef]

2. Briggs, D.E. The biochemistry of malting. In Malts and Malting, 1st ed.; Blackie Academic \& Professional: London, UK, 1998; pp. 133-218.

3. Guido, L.F. Brewing and Craft Beer. Beverages 2019, 5, 51. [CrossRef]

4. Phiarais, B.P.N.; Wijngaard, H.H.; Arendt, E.K. The impact of kilning on enzymatic activity of buckwheat malt. J. Inst. Brew. 2005, 111, 290-298. [CrossRef] 
5. Zhao, X.; Li, C.; Jiang, Y.; Wang, M.; Wang, B.; Xiao, L.; Xu, X.; Chai, D.; Dong, L. Metabolite fingerprinting of buckwheat in the malting process. J. Food Meas. Charact. 2020, 15, 1475-1486. [CrossRef]

6. Kordialik-Bogacka, E.; Bogdan, P.; Diowksz, A. Malted and unmalted oats in brewing. J. Inst. Brew. 2014, 120, 390-398. [CrossRef]

7. Klose, C.; Mauch, A.; Wunderlich, S.; Thiele, F.; Zarnkow, M.; Jacob, F.; Arendt, E.K.; Brew, J.I. Brewing with 100\% Oat Malt. J. Inst. Brew. 2011, 117, 411-421. [CrossRef]

8. Peterson, D.M. Malting oats: Effects on chemical composition of hull-less and hulled genotypes. Cereal Chem. 1998, 75, 230-234. [CrossRef]

9. Tang, M.; Wang, L.; Cheng, X.; Wu, Y.; Ouyang, J. Non-starch constituents influence the in vitro digestibility of naked oat (Avena nuda L.) starch. Food Chem. 2019, 297, 124953. [CrossRef] [PubMed]

10. Aboshora, W. Functional Foods: Effect of Superfine Grinding on Functional Properties and Antioxidant Capacities of Dietary Fiber from Cereal Bran. J. Cereal Sci. 2015, 65, 125-131. [CrossRef]

11. Isidro-Sánchez, J.; Prats, E.; Howarth, C.; Langdon, T.; Montilla-Bascón, G. Genomic Approaches for Climate Resilience Breeding in Oats. In Genomic Designing of Climate-Smart Cereal Crops, 1st ed.; Kole, C., Ed.; Springer: Cham, Switzerland, 2020; pp. 133-169.

12. Canales, F.J.; Montilla-Bascón, G.; Rispail, N.; Prats, E. Salicylic acid regulates polyamine biosynthesis during drought responses in oat. Plant Signal Behav. 2019, 14, e1651183. [CrossRef]

13. Carr, P.M.; Horsley, R.D.; Poland, W.W. Barley, oat, and cereal-pea mixtures as dryland forages in the northern Great Plains. Agron. J. 2004, 96, 677-684. [CrossRef]

14. Zhang, Y.; Zhang, L.Z.; Yang, N.; Huth, N.; Wang, E.L.; Werf, W.V.D.; Evers, J.B.; Wang, Q.; Zhang, D.S.; Wang, R.N.; et al. Optimized planting time windows mitigate climate risks for oats production under cool semi-arid growing conditions. Agric. For. Meteorol. 2019, 266-267, 184-197. [CrossRef]

15. Scholes, R.J. The Future of Semi-Arid Regions: A Weak Fabric Unravels. Climate 2020, 8, 43. [CrossRef]

16. Cammarano, D.; Ceccarelli, S.; Grando, S.; Romagosa, I.; Benbelkacem, A.; Akar, T.; Ronga, D. The impact of climate change on barley yield in the Mediterranean basin. Eur. J. Agron. 2019, 106, 1-11. [CrossRef]

17. Dawson, I.K.; Russell, J.; Powell, W.; Steffenson, B.; Thomas, W.T.; Waugh, R. Barley: A translational model for adaptation to climate change. New Phytol. 2015, 206, 913-931. [CrossRef] [PubMed]

18. Daničić, M.; Zekić, V.; Mirosavljević, M.; Lalić, B.; Putnik-Delić, M.; Maksimović, I.; Dalla Marta, A. The Response of Spring Barley (Hordeum vulgare L.) to Climate Change in Northern Serbia. Atmosphere 2019, 10, 14. [CrossRef]

19. Bennett, A.J.; Bending, G.D.; Chandler, D.; Hilton, S.; Mills, P. Meeting the demand for crop production: The challenge of yield decline in crops grown in short rotations. Biol. Rev. 2012, 87, 52-71. [CrossRef]

20. Baer-Nawrocka, A.; Kiryluk-Dryjska, E. Cereals production in selected European Union countries-political and structural implications. J. Agribus. Rural Dev. 2015, 38, 617-625. [CrossRef]

21. Leszczyńska, D.; Klimek-Kopyra, A.; Patkowski, K. Evaluation of the Productivity of New Spring Cereal Mixture to Optimize Cultivation under Different Soil Conditions. Agriculture 2020, 10, 344. [CrossRef]

22. Boczkowska, M.; Tarczyk, E. Genetic diversity among Polish landraces of common oat (Avena sativa L.). Genet. Resour. Crop Evol. 2013, 60, 2157-2169. [CrossRef]

23. Yan, W.; Fregeau-Reid, J.; Rioux, S.; Pageau, D.; Xue, A.; Martin, R.; Fedak, G.; Lajeunesse, J.; Savard, M. Response of oat genotypes to Fusarium Head Blight in Eastern Canada. Crop Sci. 2010, 50, 134-142. [CrossRef]

24. Šliková, S.; Šrobárová, A.; Šudyová, V.; Polišenská, I.; Gregová, E.; Miháli, D. Response of oat cultivars to Fusarium infection with a view to their suitability for food use. Biologia 2010, 65, 609-614. [CrossRef]

25. Langevin, F.; Eudes, F.; Comeau, A. Effect of trichothecenes produced by Fusarium graminearum during Fusarium head blight development in six cereal species'. Eur. J. Plant Pathol. 2004, 110, 735-746. [CrossRef]

26. IUSS Working Group WRB. World Reference Base for Soil Resources 2014: International Soil Classification System for Naming Soils and Creating Legends for Soil Maps; FAO: Rome, Italy, 2015.

27. Meier, U. Growth Stages of Mono- and Dicotyledonous Plants: BBCH Monograph; Julius Kühn-Institut: Quedlinburg, Germany, 2018. Available online: https://www.julius-kuehn.de/media/Veroeffentlichungen/bbch\%20epaper\%20en/page.pdf (accessed on 30 September 2021).

28. EBC-Analytica. 4.5.1 Extract of Malt: Congress Mash; Experimental Station for Variety Assessment, Chemical and Technology Laboratory: Nürnberg, Germany, 1998.

29. Kunze, W. Technology Brewing and Malting, 6th ed.; VLB Berlin: Berlin, Germany, 2019.

30. Jin, Y.; Du, J.; Zhang, K.; Guo, M. Relationships between the index of protein modification (Kolbach index) and hydrolytic enzyme production in a wheat malt. J. Inst. Brew. 2014, 120, 201-206. [CrossRef]

31. Zhou, X.; Yu, W.; Li, C. Protein content correlates with the in vitro starch digestibility of raw barley flour. Food Biosci. 2021, 43, 101292. [CrossRef]

32. Oscarsson, M.; Andersson, R.; Åman, P.; Olofsson, S.; Jonsson, A. Effects of cultivar, nitrogen fertilization rate and environment on yield and grain quality of barley. J. Sci. Food Agric. 1998, 78, 359-366. [CrossRef]

33. Micek, P.; Kulig, B.; Woźnica, P.; Sajdak, A. The nutritive value for ruminants of faba bean (Vicia faba) seeds and naked oat (Avena nuda) grain cultivated in an organic farming system. J. Anim. Feed Sci. 2012, 21, 773-786. [CrossRef]

34. Zhou, X.; Lin, W.; Tong, L.; Liu, X.; Zhong, K.; Wang, L.; Zhou, S. Hypolipidaemic effects of oat flakes and $\beta$-glucans derived from four Chinese naked oat (Avena nuda) cultivars in Wistar-Lewis rats. J. Sci. Food Agric. 2016, 96, 644-649. [CrossRef] 
35. Sterna, V.; Zute, S.; Brunava, L. Oat Grain Composition and its Nutrition Benefice. Agric. Agric. Sci. Procedia $2016,8,252-256$. [CrossRef]

36. Ullrich, S.E. Barley: Production, Improvement, and Uses, 1st ed.; Wiley-Blackwell: Chichester, WS, UK, 2010; ISBN 978-0-8138-0123-0.

37. Yin, C.; Zhang, G.P.; Wang, J.M.; Chen, J.X. Variation of beta-amylase activity in barley as affected by cultivar and environment and its relation to protein content and grain weight. J. Cereal Sci. 2002, 36, 307-312. [CrossRef]

38. Chen, J.X.; Dai, F.; Wei, K.; Zhang, G.P. Relationship between malt qualities and $\beta$-amylase activity and protein content as affected by timing of nitrogen fertilizer application. J. Zhejiang Univ. Sci. B 2006, 7, 79-84. [CrossRef] [PubMed]

39. Ping, H.; Wang, J.; Ren, G. Prediction of the total starch and amylose content in barley using near-infrared reflectance spectroscopy. Intell. Autom. Soft Comput. 2013, 19, 231-237. [CrossRef]

40. Asare, E.K.; Jaiswal, S.; Maley, J.; Baga, M.; Sammynaiken, R.; Rossnagel, B.G.; Chibbar, R.N. Barley grain constituents, starch composition, and structure affect starch in vitro enzymatic hydrolysis. J. Agric. Food Chem. 2011, 59, 4743-4754. [CrossRef]

41. Ahmed, Z.; Tetlow, I.J.; Falk, D.E.; Liu, Q.; Emes, M.J. Resistant starch content is related to granule size in barley. Cereal Chem. 2016, 93, 618-630. [CrossRef]

42. Wu, W.; Zhou, L.; Chen, J.; Qiu, Z.; He, Y. GainTKW: A Measurement System of Thousand Kernel Weight Based on the Android Platform. Agronomy 2018, 8, 178. [CrossRef]

43. Wang, K.; Fu, B.X. Inter-Relationships between Test Weight, Thousand Kernel Weight, Kernel Size Distribution and Their Effects on Durum Wheat Milling, Semolina Composition and Pasta Processing Quality. Foods 2020, 9, 1308. [CrossRef]

44. Liu, W.; Leiser, W.L.; Reif, J.C.; Tucker, M.R.; Losert, D.; Weissmann, S.; Hahn, V.; Maurer, H.P.; Würschum, T. Multiple-line cross QTL mapping for grain yield and thousand kernel weight in triticale. Plant Breed. 2016, 135, 567-573. [CrossRef]

45. Zhang, X.; Lv, L.; Lv, C.; Guo, B.; Xu, R. Combining ability of different agronomic traits and yield components in hybrid barley. PLoS ONE 2015, 10, e0126828. [CrossRef]

46. Yu, W.; Tan, X.; Zou, W.; Hu, Z.; Fox, G.P.; Gidley, M.J.; Gilbert, R.G. Relationships between protein content, starch molecular structure and grain size in barley. Carbohydr. Polym. 2017, 155, 271-279. [CrossRef]

47. Griffey, C.; Brooks, W.; Kurantz, M.; Thomason, W.; Taylor, F.; Obert, D.; Moreau, R.; Flores, R.; Sohn, M.; Hicks, K. Grain composition of Virginia winter barley and implications for use in feed, food, and biofuels production. J. Cereal Sci. 2010, 51, 41-49. [CrossRef]

48. Sallam, A.; Amro, A.; Elakhdar, A.; Dawood, M.F.; Moursi, Y.S.; Baenziger, P.S. Marker-trait association for grain weight of spring barley in well-watered and drought environments. Mol. Biol. Rep. 2019, 46, 2907-2918. [CrossRef]

49. Mahalingam, R. Analysis of the Barley Malt Rootlet Proteome. Int. J. Mol. Sci. 2020, 21, 179. [CrossRef]

50. Neylon, E.; Arendt, E.K.; Lynch, K.M.; Zannini, E.; Bazzoli, P.; Monin, T.; Sahin, A.W. Rootlets, a Malting By-Product with Great Potential. Fermentation 2020, 6, 117. [CrossRef]

51. Yu, W.; Gilbert, R.G.; Fox, G.P. Malt protein inhibition of $\beta$-amylase alters starch molecular structure during barley mashing. Food Hydrocoll. 2020, 100, 105423. [CrossRef]

52. Yu, W.; Quek, W.P.; Li, C.; Gilbert, R.G.; Fox, G.P. Effects of the Starch Molecular Structures in Barley Malts and Rice Adjuncts on Brewing Performance. Fermentation 2018, 4, 103. [CrossRef]

53. Hill, A.E.; Stewart, G.G. Free Amino Nitrogen in Brewing. Fermentation 2019, 5, 22. [CrossRef]

54. Ferreira, I.M.; Guido, L.F. Impact of Wort Amino Acids on Beer Flavour: A Review. Fermentation 2018, 4, 23. [CrossRef]

55. Stewart, G.G.; Hill, A.E.; Lekkas, C. Wort FAN-Its characteristics and importance during fermentation. J. Am. Soc. Brew. Chem. 2013, 71, 179-185. [CrossRef]

56. Stewart, G.G. Saccharomyces species in the Production of Beer. Beverages 2016, 2, 34. [CrossRef]

57. Niu, C.; Han, Y.; Wang, J.; Zheng, F.; Liu, C.; Li, Y.; Li, Q. Malt derived proteins: Effect of protein Z on beer foam stability. Food Biosci. 2018, 25, 21-27. [CrossRef]

58. Siebert, K.J. Recent discoveries in beer foam. J. Am. Soc. Brew. Chem. 2014, 72, 79-87. [CrossRef]

59. Błażewicz, J.; Liszewski, M.; Zembold, A. Technological properties of worts obtained from malts of naked barley grain. Acta Sci. Pol. Technol. Aliment. 2007, 6, 37-48.

60. Błażewicz, J.; Liszewski, M.; Zembold-Guła, A.; Kozłowska, K.; Szwed, Ł. Liczba Kolbacha jako ważny wskaźnik wartości przetwórczej ziarna jęczmienia browarnego. Fragm. Agron. 2013, 30, 46-53.

61. Preedy, V.R. Overveiw of Manufacturing Beer: Ingredients, Processes and Quality Criteria. In Beer in Health and Disease Prevention, 1st ed.; Academic Press: London, UK, 2011; pp. 3-16.

62. Karimi, M.; Kheiralipour, K.; Tabatabaeefar, A.; Khoubakht, G.M.; Naderi, M.; Heidarbeigi, K. The effect of moisture content on physical properties of wheat. Pak. J. Nutr. 2009, 8, 90-95. [CrossRef]

63. Sologubik, C.A.; Campañone, L.A.; Pagano, A.M.; Gely, M.C. Effect of moisture content on some physical properties of barley. Ind. Crop. Prod. 2013, 43, 762-767. [CrossRef]

64. Gely, M.C.; Pagano, A.M. Effect of moisture content on engineering properties of sorghum grains. Agric. Eng. Int. CIGR J. 2017, 19, 200-209.

65. Jung, H.; Lee, Y.J.; Yoon, W.B. Effect of moisture content on the grinding process and powder properties in food: A review. Processes 2018, 6, 69. [CrossRef]

66. Aprodu, I.; Banu, I. Milling, functional and thermo-mechanical properties of wheat, rye, triticale, barley and oat. J. Cereal Sci. 2017, 77, 42-48. [CrossRef] 
67. Virkki, L.; Johansson, L.; Ylinen, M.; Maunu, S.; Ekholm, P. Structural characterization of water-insoluble nonstarchy polysaccharides of oats and barley. Carbohydr. Polym. 2005, 59, 357-366. [CrossRef]

68. Cassol, L.C.; Piva, J.T.; Soares, A.B.; Assmann, A.L. Yield and structural composition of oat and ryegrass subjected to different periods of cutting and nitrogen fertilization. Rev. Ceres 2011, 58, 438-443. [CrossRef]

69. Welch, R.W.; Yong, Y.Y. The effects of variety and nitrogen fertiliser on protein production in oats. J. Sci. Food Agric. 1980, 31, 541-548. [CrossRef]

70. White, E.; Finnan, J. Crop structure in winter oats and the effect of nitrogen on quality-related characters. J. Crop Improv. 2017, 31, 758-779. [CrossRef]

71. Blazewicz, J.; Liszewski, M. The grain of naked barley of 'Rastik' cultivar as a raw material for malts of pilzen type production. Acta Sci. Pol. Technol. Aliment. 2003, 2, 63-74.

72. Najamuddin, U.; Gorji, S.; Fitzgerald, M. Genotypic variability in the composition of soluble protein from rice bran-opportunities for nutrition. J. Food Compost. Anal. 2021, 103, 104077. [CrossRef]

73. Nogala-Kałucka, M.; Kawka, A.; Dwiecki, K.; Siger, A. Evaluation of bioactive compounds in cereals. Study of wheat, barley, oat and selected grain products. Acta Sci. Pol. Technol. Aliment. 2020, 19, 405-423. [PubMed]

74. Rafińska, K.; Pomastowski, P.; Rudnicka, J.; Krakowska, A.; Maruśka, A.; Narkute, M.; Buszewski, B. Bioactive compounds and antioxidant activity of wheat bran and barley husk in the extracts with different polarity. Int. J. Food Prop. 2019, 22, 646-658.

75. Gasiński, A.; Błażewicz, J.; Kawa-Rygielska, J.; Śniegowska, J.; Zarzecki, M. Analysis of Physicochemical Parameters of Congress Worts Prepared from Special Legume Seed Malts, Acquired with and without Use of Enzyme Preparations. Foods 2021, 10, 304. [CrossRef] 